\title{
Candidacy, political parties and representative government in Nigeria
}

\author{
Authors: Rotimi Adeforiti \\ Submitted: $\quad$ 11. October 2018 \\ Published: $\quad$ 15. October 2018 \\ Volume: 5 \\ Issue: 8 \\ Affiliation: Kings University, Odeomu, Nigeria \\ Languages: English \\ Keywords: $\quad$ Candidate, Political party, Representative Government, Primary \\ election, Internal democracy. \\ DOI: $\quad 10.17160 /$ josha.5.8.481
}

\section{Abstract:}

The study using secondary source of data, such as the Electoral Act (2010), newspaper articles, journal articles, fourth republican constitution of Nigeria, etc. identified the processes involved in the emergence of a candidate for election in Nigeria and also examined the implications of the process for representative government in Nigeria. The paper revealed that the process involved in the emergence of a candidate from political party platform for election is by shadow or primary election or internal democracy. The paper also revealed that the process of a candidate's emergence on a political party platform is a determinant of sustainable democratic practice in Nigeria. The study concludes that for democracy to be sustained in Nigeria, qualified party members must be allowed to take active part in primary elections and qualified adult citizens to vote in general elections.

\section{JOSHA Jumana ostemene. Humanities and Arts}




\title{
Candidacy, Political parties and Representative Government in Nigeria
}

\author{
Rotimi Adeforiti \\ Department of Political Science, \\ Kings University, Odeomu, Nigeria. \\ rotimioduola@gmail.com, r.adeforiti@kingsuniversity.edu.ng.
}

\author{
Damilola Ebenezer Abiola \\ Department of Political Science, \\ Kings University, Odeomu, Nigeria. \\ abioladamilola2022@gmail.com, deemajor2022@yahoo.com \\ Ibidamola Adedayo Anibijuwon \\ Department of Political Science, \\ Kings University, Odeomu, Nigeria. \\ dammyanibijuwon@yahoo.co.uk, ia.anibijuwon@kingsuniversity.edu.ng
}

\begin{abstract}
.
The study using secondary source of data, such as the Electoral Act (2010), newspaper articles, journal articles, fourth republican constitution of Nigeria, etc. identified the processes involved in the emergence of a candidate for election in Nigeria and also examined the implications of the process for representative government in Nigeria. The paper revealed that the process involved in the emergence of a candidate from political party platform for election is by shadow or primary election or internal democracy. The paper also revealed that the process of a candidate's emergence on a political party platform is a determinant of sustainable democratic practice in Nigeria. The study concludes that for democracy to be sustained in Nigeria, qualified party members must be allowed to take active part in primary elections and qualified adult citizens to vote in general elections.
\end{abstract}

Keyword: Candidate, Political party, Representative Government, Primary election, Internal democracy.

\section{Introduction}

The practice of democracy in the Nigeria's fourth republic is significant in the democratic history of the country for the fact that the continuous practice of representative democracy is closer to two decade without any intervention of the military, elections has instituted by the constitution has the means of political power taking in the country is still maintained, there have been five 
successful general elections with preparation for future elections, inter-ethnic, intra and interparty transfer of political power have been completed, there has been formation and merger of political parties (since return to democracy in 1999) and the various predictions and thought of Nigeria's disappearance (due to electoral violence and by secession) has been challenged and this is in conformity with the thought of Omilusi \& Ajibola (2016) that 'where democracy survives for a long period of time, it is because political parties, among other vital institutions, are well established, and have played the role expected of them'

The return of Nigeria to democracy in 1999 through the enactment of a supreme constitution did necessitated the adoption of election as the means of exercising governmental power by the candidate of a political party, who having satisfied the requirements of extant laws is, declared winner by the electoral commission (that is the Independent National Electoral Commission (INEC)) and also, the conduct of political activities is guided by the provision of the constitution (to which other laws are subordinate) and supervised by INEC.

In the fourth republic, Political parties were formed from political association by registration in lined with the requirements of the constitution and this is because 'Political parties are traditionally the most significant intermediary organization in democratic societies' (Orji cited in Akubo \& Yakubu, 2014) and also, Omotola (cited in Adekeye, 2017; Akubo \& Yakubu, 2014) claimed that neither democracy nor democratic societies are possible in the absence of political parties. This was why Adekeye (2017) stated that

It is incontestable that political parties have remained vital and indispensible tools in institutionalizing democracy in most democratic polity in the world today. Arising from the catalytic feature of political parties, they serve an intermediate role in democratic societies by acting as a connecting cord between the government and the people, thereby ensuring all tenets of democracy are upheld in the country.

In the observation of Newton \& Van Deth (2005, Pp. 221)

Democratic government is party government: electoral competition is largely party competition; parliamentary politics are invariably party politics; and government is rarely anything but party government. For better or for worse, political parties pervade all aspects of government and politics in democracies. They mediate between citizens, at the bottom of the political system, and parliamentary parties, presidents and prime ministers, at the top, and they span the segments of society (classes, generations, genders, ethnic groups, religions, regions, voluntary organisations, etc.).

Democracy and the practice of party-democracy in Nigeria have been experimented at two different periods (that is before independence and after independence). Before Independence, the foundation for Nigeria democracy was laid through the Clifford constitution. The constitution introduced elective principle, allowed election for four representatives in the unofficial capacity 
created by the constitution in the legislature, and these among others did influence the formation of the first and subsequent political parties and their activities further influenced the writing and rewriting of constitutions: Arthur Richard (1946), John Macpherson (1951), Oliver Lyttelton (1954)).

In the Aftermath of the Independence constitution, there were 'epileptic' democratic practice in Nigeria, the Independence/ First republican constitution was suspended by the military after the first military cope d'état of 1966 due to the existence of political parties along ethnic line and the popular (post election violence in the then, Western region, 1965) fallout of the political activities of the period (that is 'operation wet $e$ '). The Second republican constitution was suspended by the military due to allegation of corruption and wasteful spending by government officials and the rigging of 1983 on political party ground (in favour of the ruling National Party of Nigeria). Third Republic could not hold due to military ruler's refusal to relinquish political power to democratically elected president despite the existence of a supreme constitution and election of representative by the people on the two political parties formed and financed by the Federal Military Government (FMG) under Gen. Ibrahim Babangida. In an interview conducted with General Ibrahim Babangida and published in Daily Post on 12 June, 2017, Babangida stated that

He was compelled to nullify the election because of security threats to the enthronement of a democratic government at that time.

He also said that having been in government at the time, he and the Armed Forces Ruling Council (AFRC) knew that the new democratic government to be installed would sooner than later be toppled through another military coup d'état, which he said his government wanted to avoid.

He said his regime had decided that it would be the last that would ascend the seat of power through coup, adding that it would make no sense to install a democratic government that would be truncated within another six months.

He said, "June 12 was accepted by Nigerians as the best of elections in Nigeria. It was free and fair. But unfortunately, we cancelled that election.

Due to the above, the Fourth Republican constitution having identified the challenges that confronted the erstwhile republics in Nigeria did adopted series of steps through which it intended to make political party work and democracy sustained through political party activities in Nigeria's fourth republic. The first step in this direction (by the constitution) is the existence of a supreme constitution which makes provision for political parties' emergence by registration and in accordance with the provisions of the constitution. Also, there was the enactment of an Electoral Act in order to further encourage internal democratic practice in political parties' activities especially the emergence of party candidate in the country.

In the fourth republic, Political activities have resurrected in Nigeria for close to two decade and such question has the best means of choosing candidates in a political party emerged again. The Electoral Act (FGN, 2010) has required the existence of political parties in accordance with the provisions of the constitution in section 222 (FGN, 1999), and also the choice of party candidate by either direct or indirect primary methods. 


\section{Statement of the problem}

The practice of democracy by election and political parties is not new in Nigeria; the practice has been in place since the enactment of Clifford's constitution (during colonialism) and transited through independence constitution (to post colonialism). The practice and suspension of democracy in Nigeria (especially between 1966-1975 and 1983-1999) were worrisome for Nigerian, Africans and the International Community because of the influence of events in Nigeria on African community in general and the need for democracy in Nigeria. Since independence, there have been practice of 'unsuccessful' democracy in Nigeria and as a result, republics have been hijacked by the military due to a host of factors among which ethnic politics (such as ethnic political party, ethnic identity in election), low level of political literacy or education, and lack of defined rule guiding political activities are some of the major influencing factor.

The practice of democracy in Nigeria's fourth republic is about two decade (1999-2018) with its significant contributions to representative government in Nigeria and Africa as a whole. The current practice of democracy (since 1999) in Nigeria can be said to be in its longest phase in the and most of the features of democracy in the fourth republic have been formed and constituted since Independence. The enactment of the fourth republican constitution is believed to be a summation of constitutions from 1914 till date. The study is conducted to investigate the process of candidate emergence within a political party and the implications of the emergence for political offices holder, hence this study.

\section{Limitation of the study}

The study is concerned with the political process for the emergence of a candidate from political parties in the Nigeria's fourth republic and as such, attention is given to the emergence of representative government through primary election for the 2019 general elections in Nigeria. The study purposefully focus on such offices has governor and president of the All Progressive congress (APC) and the Peoples Democratic Government (PDP).

\section{Methodology, Definition of concept and Theoretical framework}

The study made use of literature survey method. Literatures on Nigerian government and politics were purposefully selected for analyses, documents (such as the constitution of 1999 and Electoral Act 2010 were subjected to analyses). Newspaper article, Journal article etc. constituted additional sources of data. The essence of using secondary data was to sample opinions of writers in getting relevant information pertinent to the study. Datas were presented and analysed using descriptive method.

The following concepts were defined, viz

Primary Election: The means of constituting government in a democratic state is election. The constitution allowed the same for political parties' in presenting its candidates and hence primary election. Primary election (otherwise known as internal democracy or shadow election) is the 
means of choosing representatives for elections in a political party by member of that party in a way acceptable to the constitution.

Internal democracy: The word 'Democracy' was coined from two Greek words 'Demo' and 'Kratia' meaning 'People' and 'Government' respectively. The word has been variously defined in literature and subjected to diverse standard. Basically, democracy is usually defined in term of election or emergence of leader as a system in which the people come together periodically to choose their representatives in government and this study defines democracy accordingly.

Internal democracy applies to the conduct of political parties' activities and it is taken to mean choice of candidate, representative and party executives etc. through election by political party members.

Political party: A political party is a form of interest group. The objective of a political party as an interest group is the contest of election, winning of election and formation of government in a state. A political party operates within the specification and allowance of the constitution. The interest of the political party is protection of the constitution and or national interest of the state.

A political party is an association of people sharing the same party ideology and its objective is to contest elections, win elections and form government in a state.

Candidate: A person seeking election to political office on the platform of a political party is a candidate. The candidate usually emerged in a series of ways (such as imposition by party elite, grant of candidacy as compensation, election, etc.). The most popular way for the emergence of a candidate is from internal democracy or what is popularly called primary or shadow election. Member of the party are expected to participate directly or indirectly; directly by themselves or indirectly by proxy or delegate.

The study adopts Elite theory for analyses. The adoption of Elite theory is influenced by the believe that in any organisation there must be the place of individual or certain individual whose aims and objectives influences the decision making in the organisation, and as such, in the word of Robert Michels (cited in Higley, 2008) that "Who says organization says oligarchy."

Higley (2008) noted that 'Elites derive from a fundamental and universal fact of social life, namely, the absence in any large collectivity of a robust common interest'. In the observation of Higley \& Burton (cited in Pakulski, 2012) that "

Due to their strategic positions and resources under their control, elites - that is, small groups of "persons who are able, by virtue of their strategic positions in powerful organizations and movements, to affect political outcomes regularly and substantially"- have the power that the majority of people or non-elites lack, and they make systematic use of their power in both democratic and nondemocratic polities “

In any political party like a society, there are diverse interests which are championed by different individuals at different point in time and the interests are represented by individuals that desires to contest primary elections in order to become a candidate of the political party for election. The 
candidate stands for the overall decision of the party in order to emerge a representative of the people. While a candidate emerged, the other interests are allowed to exist.

\section{The Emergence of Political Party and Candidacy in Nigeria's Fourth Republic}

The emergence of political parties in Nigeria (like in other British colonised Africa countries) is traceable to the colonial constitution that introduced elective principle and created four seats in unofficial capacity in the legislature in 1922. In the observation of Salih (2003, Pp. 2), in a work Titled: African Political Parties; Evolution, Institutionalisation and Governance, observed that

Political parties in Africa emerged during the colonial rule (which was neither democratic nor legitimate). In a sense, African political parties emerged in a nondemocratic setting, which to a large extent informed their practice during independence.

Candidacy on political party platform started with Clifford constitution, the constitution did encourage the formation of the first political party (Nigeria National Democratic Party in 1923 by Herbert Macaulay) after the introduction of elective principle and creation of a new legislative council (in which four Nigerians were to be elected). The constitution did outline criteria to be met before a person is allowed to vote in elections ranging from and including the earning of gross annual income of a hundred pounds as salary, possession of first class residence in Lagos, male gender, senior civil servant, etc. The requirements of the constitution for emergence or qualification as a candidate in an election on party platform under the constitution cannot be lesser than these requirements stated for voters. The formation of the first political party in Nigeria was led by one man and the emergence of party candidate (that contested the election and won) because of the requirements of the constitution must have influenced the elite influence. It may be logically concluded that there was no internal democracy in political parties in the Clifford's constitution and the situation continued in different dimension in Nigeria politics till 1963.

Colonial constitutions have been criticised for their failure to encourage democratic practice within a political party (internal democracy) at a period of foundational democracy. The independence and Republican constitution of Nigeria can be taken as a replica or summation of the colonial constitution and these did manifest the reality of lack of internal democracy. The independence constitution did not defined what a political party is, the processes and procedure for their formation, etc. Political parties existed but were not constitutionally known. This therefore may be responsible for the existence of political parties based on ethno-geographical boundary. The view of Kirk Greene (cited in Obi, 2000) corroborated the above analyses that

... a common feature of all these colonial constitutions was that they were not designed to build a Nigerian state, rather they were measures of administrative strategies for better administration of the colonial state although occasionally they bent to the realities of increasing political consciousness among the colonial elite.

The return of Nigeria to democracy through the enactment or proclamation of the fourth republican constitution ushered in democracy with political party as means of power taking. The 
constitution in accordance with section 320 (FGN, 1999) stated that 'The provision of this Constitution shall come into force on $29^{\text {th }}$ day of May 1999' and did took off on the date. The constitution instituted election as the means of power taking and political party as the platform for power taking. The practice of democracy in the fourth republican constitution can be said to be the summations of the events that had taken place on the political platform of Nigeria since independence and as such, the fourth republican constitution rather than complicating issues of democracy in Nigeria has outline in certain section of the its provision procedure to follow for the emergence of political party, emergence of candidate from political parties to contest election, criteria for winning elections, etc. The study identified the processes involved in the emergence of a candidate from a political party and influence on democracy in Nigeria.

\section{Presentation and Analyses of Data}

The emergence of a political parties' in democracies is traceable to the provisions of the constitution, the constitution among other institutions created an electoral commission or body to oversee political activities, and the constitution also defines a political party, outlines the criteria's which a political association must fulfil to become a political party, defines the roles of the political party, states the process for the emergence of a candidate on political party platform, and also states other laws which exists to guide political parties'. In this manner, while the independence and first republican constitution failed to define a political party, the Republican constitutions of 1979, 1989 and 1999 defined a political party in a more similar way and thus

political party" includes any association whose activities include canvassing for votes in support of a candidate for election to the office of President, VicePresident, Governor, Deputy Governor or membership of a legislative house or of a local government council.

The first republican constitution in section 50 (1) (FGN, 1963) created an electoral commission by the declaration that 'There shall be an Electoral Commission for the Federation' of Nigeria. The constitution by virtue of this section created an autonomous body which oversee the regulation of political activities in the country. Similarly, the fourth republican constitution in Section 153 (1 f) (FGN, 1999) stipulated that 'There shall be established for the Federation the Independent National Electoral Commission'. By the declaration of the constitution, there came into existence the Electoral Commission which is to be known as the 'Independent National Electoral Commission (INEC)' in the fourth republic.

The constitution setting up an independent body for the monitoring of the political process equally set the rules for the emergence of a political party. The 1963 constitution did provided for an electoral commission but failed to define a political party and as such political parties existed without constitutional standard. The implication of this may be a direct influence on the development of an ethnic political party. In order to avoid the errors of the first republic, the fourth republican constitution did not only define a political party, it equally stated the 
requirements for the emergence of a political party, distinguishing political parties from political association. The constitution in section 229 (FGN, 1999) stated thus

In this Part of this chapter, unless the context otherwise requires "association" means anybody of persons corporate or unincorporated who agree to act together for any commission purpose, and includes an association formed for any ethnic, social, cultural, occupational religious purpose; and "political party" includes any association whose activities include canvassing for votes in support of a candidate for election to the office of President, Vice-President, Governor, Deputy Governor or membership of a legislative house or of a local government council.

The constitution in section 222 (a-f) stated the procedure to be followed in the emergence political parties thus

No association by whatever name called shall function as a party, unless -

(a) the names and addresses of its national officers are registered with the Independent National Electoral Commission;

(b) the membership of the association is open to every citizen of Nigeria irrespective of his place of origin, circumstance of birth, sex, religion or ethnic grouping;

(c) a copy of its constitution is registered in the principal office of the Independent National Electoral Commission in such form as may be prescribed by the Independent National Electoral Commission;

(d) any alteration in its registered constitution is also registered in the principal office of the Independent National Electoral Commission within thirty days of the making of such alteration

(e) the name of the association, its symbol or logo does not contain any ethnic or religious connotation or give the appearance that the activities of the association are confined to a part only of the geographical area of Nigeria; and

(f) the headquarters of the association is situated in the Federal Capital Territory, Abuja.

It can be inferred from above that in section 222 (c) (FGN, 1999) that the constitution of any political party (randomly or purposefully) selected in Nigeria from the currently registered ninety-one political parties must conform to the orientation of the constitution, Also, section 222 (d) (FGN, 1999) above confirm that a political party must update the INEC of any changes in its constitution. More so, there was the enactment of an Electoral Act in 2010 to replace the Electoral Act 2006. The Electoral Act (FGN, 2010) stated in section 78 (1-6) with regard to a political party existence thus

A political association that complies with the provisions of the Constitution and this Act for the purposes of registration shall be registered as a political party. Provided that such application for registration as a political party shall be duly submitted to the Commission not later than 6 months before a general election. 
The Commission shall, on receipt of the documents in fulfilment of the conditions stipulated by the Constitution, immediately issue the applicant with a letter of acknowledgement stating that all the necessary documents had been submitted to the Commission.

If the Association has not fulfilled all the conditions under this section, the Commission shall within 30 days from the receipt of its application notify the association in writing stating the reasons for non-registration.

A political association that meets the conditions stipulated in the Constitution and this Act shall be registered by the Commission as a political party within 30 days from the date of receipt of the application, and if after the 30 days such association is not registered by the commission unless the Commission informs the association to the contrary' it shall be deemed to have been registered.

An association which, through the submission of false or misleading information pursuant to the provisions of this section, procures a certificate of registration shall have such certificate cancelled.

An application for registration as a political party shall not be processed unless there is evidence of payment of administrative fee as may be fixed from time to time by the Commission.

It is very clear that a political party exists and functions in Nigeria as long as it has been registered, in line with the Electoral Act and the Constitution, by INEC. However, the major objective of a political party like the spirit of the (1999) Constitution is controlling government which must tallies with the national integration objective of the constitution. The holding of public office by a political party is through the constitution and the constitution adopted election, then there is the need to assess the processes in the emergence of a candidate in a political party or primary election. The Electoral Act (FGN, 2010) in Section 87 (1-2) stated that

A political party seeking to nominate candidates for elections under this Act shall hold primaries for aspirants to all elective positions.

The procedure for the nomination of candidates by political parties for the various elective positions shall be by direct or indirect primaries.

It is useful at this point to state clearly that though the Electoral Act as well as the constitution do believe in the nomination of candidate by political parties through primary elections for general election, there is the nomination of candidates for primaries either by self or by groups which is signalled by the candidates purchase of 'expression of interest and nomination form'. There is usually the purchase of nomination form by or for each candidate usually at a price fixed by the political party. In preparation for (2019) General Election for instance, Odebode \& Alechenu (2018) reported that the All Progressive Party advertised the sale of forms for 'expression of interest and nomination form' thus

The sale of nomination form for President is 44.5 million naira, The governorship aspirant pays $\mathrm{N} 22.5 \mathrm{~m}$ for nomination form, 
Fabiyi (2018) equally reported that the Peoples Democratic Party (PDP) advertised the sale of form for expression of interest and nomination of candidate and state thus

Presidential aspirants were to pay a total of N12m, Governorship aspirants pays N6m

INEC recently stated that 'after the conduct of party primaries, the chairman of the party is the only one that can forward the name of candidates'. Akinkuotu (2018) reported thus

The Independent National Electoral Commission has warned the 91 political parties that it will not receive communication from any organ of the party except the chairman and the National Executive Council of the party. ....... in the past, state chapters and the national body of parties would send different names of political candidates for the same office....... the Supreme Court had ruled that the national body of a political party was the one charged with the duty of communicating with INEC.

Consequently, the constitution has empowered the INEC to fix date for the conduct of all elections (both primaries and general elections) in the country. In compliance with the directive, political parties presents candidates for election after primary elections. However, the failure of any political party to meet the deadline or comply with the rules for the conduct of primary elections means absence of candidate of the party in elections. In line with this, is the report of Aluko (2018) on All Progressive Congress (APC) that

The INEC stated ......... that the APC failed to conduct primaries for elective offices and would therefore not field candidates for the governorship and legislative elections in Zamfara.

The fourth republican constitution (FGN, 1999) stated in Section 78 thus

The registration of voters and the conduct of the elections shall be subject to the direction and supervision of the Independent National Electoral Commission.

In declaring the method of election, the Electoral Act (FGN, 2010) in Section 108 (5) stated that 'Voting shall be by open-secret ballot'. Consequently, Section 98 (2) (FGN, 1999) stated that 'Except as otherwise provided by this Constitution, the required majority for the purpose of determining any question shall be a simple majority'. In announcing the result of election and declaration of winner in any election in Nigeria, the Electoral Act state in Section 27 (1- 2) thus

(1) The Results of all the elections shall be announced by-

(a) the Presiding Officer at the Polling unit;

(b) the Ward Collation Officer at the Ward Collation Centre; 
(c) the Local Government or Area Council Collation Officer at the Local Government! Area Council Collation Centre;

(d) the State Collation Officer at the State Collation Centre; and

(2) The Returning Officer shall announce the result and declare the winner of the election at-

(a) Ward Collation Centre in the case of Councillorship election in the Federal Capital Territory;

(b) Area Council Collation Centre in the case of Chairmanship and Vice

Chairmanship election in the Federal Capital Territory;

(c) State Constituency Collation Centre in the case of State House of Assembly election;

(d) Federal Constituency Collation Centre in the case of election to the House of Representatives;

(e) Senatorial District Collation Centre in the case of election to the Senate;

(f) State Collation Centre in the case of election of a Governor of a State;

(g) National Collation Centre in the case of election of the President; and Announcement of election results

(h) the Chief Electoral Commissioner who shall be the Returning Officer at the Presidential election.

\section{Implication of primary election for Political Party in the fourth republic}

The Electoral Act (FGN, 2010) in Section 87 (1-2) had declared that 'A political party seeking to nominate candidates for elections under this Act shall hold primaries for aspirants to all elective positions' and 'The procedure for the nomination of candidates by political parties for the various elective positions shall be by direct or indirect primaries'. Flowing from this reality, there is the need to critically examine the implications of the direct and indirect primary election.

The emergence of a candidate for election from a political party is through primary election which is conducted by the political party (in accordance to relevant laws and Act) using either direct or indirect primary method. In the case of direct primary, the 'card carrying' members of the political party are allowed to participate in the exercise by themselves. This method stands to confer legitimacy on the emerged candidate and it is the most democratic form of primary election.

On the other hand, the indirect primary involved the selection of delegate by party member and the delegates in turn represent the interest of local party member in choosing the party flag bearer in an election. This option seems easier to understand when compared to the direct method. The process is very simple in that number of participating delegates is clearly defined and cannot be forged. However, the system may bring about the evolution of elite within the political party structure which of course may prevent adequate representation in the choice of representative. The delegates become elite as a result of their position within the party structure.

The example of the process that can be cited is obtainable in the fourth republic and as contained in the Electoral Act (FGN, 2010). The two samples of political parties are Peoples Democratic Party (PDP) and All Progressive Congress (APC). The two political parties in term of 
membership and number of seats in the National Assembly are the major party. The PDP in preparation for presidential election of February 19, 2019 (INEC) adopted the indirect primary method. In which case, delegate chosen by the member of the party, represented their interest. On the other hand, the APC adopted direct primary in selection of its aspirant.

The basic inference that can be made from the above is that objectively, there is absence of godfathers in politics at least the emergence of candidate by internal democracy which was either direct or indirect which did required the participation of party member either by themselves or party delegate. More so, there is the absence of ethnic politics. Political parties are national in outlook and orientation, formed with broad based member and not by member of an ethnic group. The implications of candidacy for political parties are that it allows political parties to live up to the desire of her members, it can help in erasing godfather politics in Nigeria and also, the practice can help to deepen democratic practise in Nigeria as a multi-ethnic state.

\section{Conclusion}

The study concludes that for democracy to be sustained in Nigeria, party members must be allowed to take active part in primary elections by themselves. The active participation of qualified adult citizens in a political party (primary election) and general elections will foster integration and promote unity in Nigeria, eradicate godfather politics, and helped in the sustenance of democratic practice in the country.

\section{Recommendation}

The paper recommends that public orientation by INEC on the process involved in the emergence of a candidate to representative through elections should be made open to general public. This will enable Nigerians to understand the process involved in elections and on the long run ensures integration and sustained democratic practice in the country. 
References

Adekeye, Muinat Adetayo (2017). Party Primaries, Candidate Selection and Intra-Party Conflict in Nigeria: PDP in Perspective. Covenant University Journal of Politics \& International Affairs, Vol. 5 (1), Pp. 22-39.

Akinkuotu, Eniola (2018, September 8). 2019: Only national party chairmen can submit candidates' names, says INEC. PUNCH. https://punchng.com/2019-only-national-partychairmen-can-submit-candidates-names-says-inec/

Akubo, A. Aduku \& Yakubu, Adejo Umoru (2014). Political Parties And Democratic Consolidation In Nigeria's Fourth Republic. Global Journal of Political Science and Administration, Vol.2 (3), Pp.79-108. http://www.eajournals.org/wp-content/uploads/Political-Parties-and-DemocraticConsolidation-in-Nigeria---s-Fourth-Republic.pdf

Awofeso, Olu. (2014). Constitutional Development in Nigeria; Historical and Political Analysis, Lagos; MacGrace Publishers.

FGN (1963). The Constitution of the Federal Republic of Nigeria. Federal Government of Nigeria.

FGN (1979). The Constitution of the Federal Republic of Nigeria. Federal Government of Nigeria.

FGN (1999). The Constitution of the Federal Republic of Nigeria. Federal Government of Nigeria.

FGN (2010). Electoral Act. Federal Government of Nigeria.

Higley, J. (2008). Elite theory in political sociology. Texas: University of Texas in Austin http://paperroom.ipsa.org/papers/paper_4036.pdf.

INEC (nd). Political Parties. http://www.inecnigeria.org/?page_id=18

Jinadu, Adele L. (2011). Inter-Party Dialogue in Nigeria: Examining The Past, Present \& Future https://nairametrics.com/wp-content/uploads/2013/03/INTER-PARTY-DIALOGUE-INNIG.pdf

Kamrava, Mehran (1996). Understanding Comparative Politics; a Framework for Analysis. New York, NY, Routledge.

Newton, Ken, \& Van Deth, Jan W. (2005). Foundations of Comparative Politics. New York, Cambridge University Press. 
Nwachukwu, J. O. (2017). Why I annulled June 121993 Presidential election - Babangida. Daily Post available at http://dailypost.ng/2017/06/12/annulled-june-12-1993presidential-election-babangida/

Obi, Cyril (2000). Last Card: Can Nigeria Survive Another Political Transition? African Journal of Political Science, 5 (2), Pp. 67-86.

Odebode, Niyi \& Alechenu, John (2018, September 5). APC presidential, gov aspirants to pay N45m, N22.5m for forms. PUNCH. https://punchng.com/apc-presidential-gov-aspirantsto-pay-n45m-n22-5m-for-forms/

Olusola Fabiyi (2018, August 28). 2019: PDP begins sale of nomination forms. PUNCH https://punchng.com/2019-pdp-begins-sale-of-nomination-forms/

Pakulski, Jan (2012). John Higley's work an Elite foundations of Social theory and politics. Historical Social Research, 37(1), 9-20. https://doi.org/10.12759/hsr.37.2012.1.9-20.

PUNCH (2018, August 17). INEC releases 2019 general elections notice in Lagos. PUNCH. https://punchng.com/inec-releases-2019-general-elections-notice-in-lagos/

Salih, Mohamed, M.A. (ed.) (2003). African Political Parties: Evolution, Institutionalisation and Governance. London, Pluto Press.

Sobechi, Leo (2017, July 2). INEC and mushrooming of political parties. The Guardian. https://guardian.ng/saturday-magazine/cover/inec-and-mushrooming-of-political-parties/

Aluko, Olaleye (2018, October 10). 2019 election: APC Zamfara won't field candidates - INEC. PUNCH. https://punchng.com/2019-election-apc-zamfara-wont-field-candidates-inec/ 


\section{About the Authors}

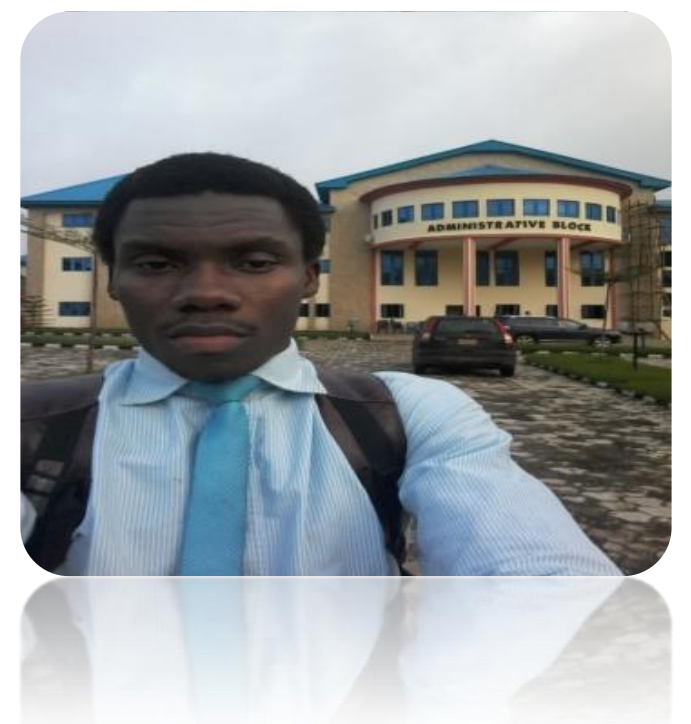

Rotimi Adeforiti is a Lecturer in the Department of Political Science, Kings University, Odeomu, Nigeria. He is currently a Ph. D student of the Department of Political Science, Obafemi Awolowo University, Ile-Ife, Nigeria. He has a paper titled: Implications of ethnic identity for National Integration in Nigeria published by Journal of Pan African Studies. He has interest in comparative politics, Nigerian government and politics and political theory.

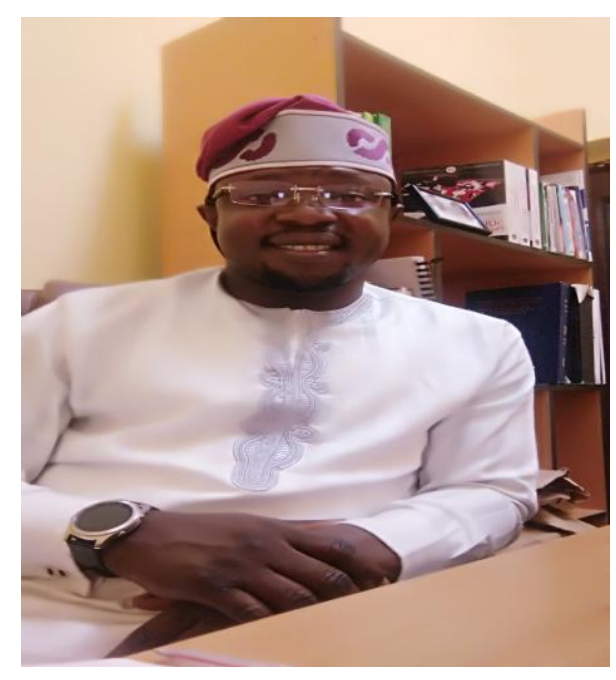

Damilola Ebenezer Abiola is a Lecturer in the Department of Political Science, Kings University, Ode-omu, Osun State, Nigeria. He is rounding up is $\mathrm{Ph}$.D. programme in the Department of Sociology, Faculty of Social Science, Ekiti State University, Ado-Ekiti, Nigeria. He has published several papers and specialised in work and labour relation, political sociology, gerontology etc. He is current an observer for United Nation women participation in politics programme (Osun and Ekiti State). 


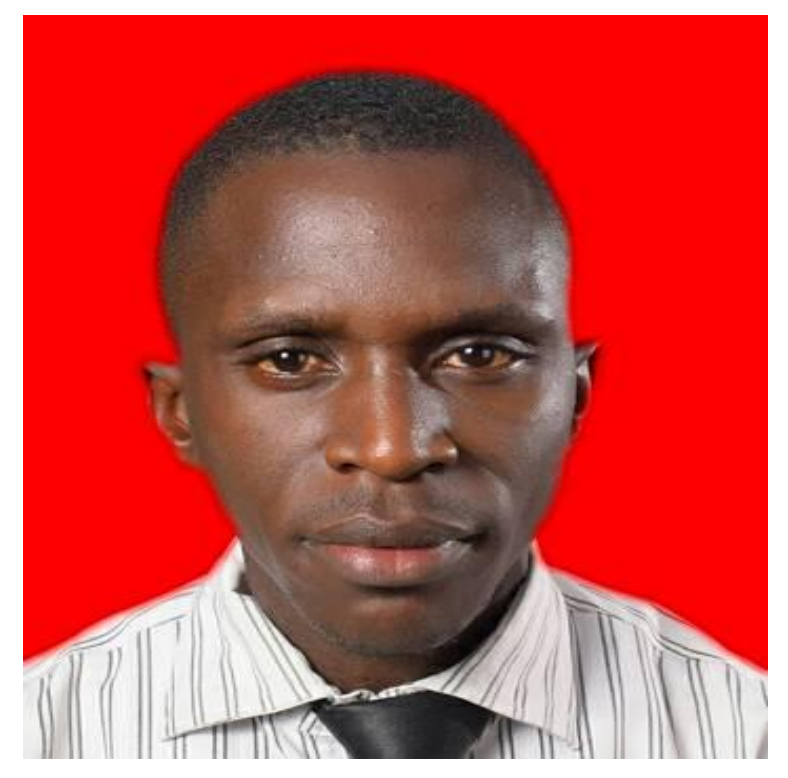

Ibidamola Adedayo Anibijuwon is a Lecturer in the Department of Political Science, Kings University, Odeomu, Nigeria. 